\title{
NOZIEDZİGI IEGŪTĀ KONFISKĀCIJAS IESPĒJAS UN PAMATS
}

\section{POSSIBILITIES AND GROUNDS FOR CONFISCATION OF CRIME PROCEEDS}

\author{
Gunārs Kūtris, $M g$. iur.
}

Latvijas Universitātes Juridiskās fakultātes

Krimināltiesisko zinātṇu katedras lektors

\begin{abstract}
Summary
Crime proceeds must be confiscated. There is no discussion about it. The article deals with situations where a criminal origin of property has not been proven but is presumed, and, consequently, the property is subject to confiscation. This is particularly relevant in the process in rem or in the special process for the crime proceeds. Here, the decision of confiscation takes place before the criminal proceedings on the person's fault have been completed. Therefore, it is important to respect the preconditions for initiating this process, that must be established: firstly, whether there is a set of evidence on the criminal origin of the property. In this process, the fault of the person may not be assessed, but only the evidence of the origin of the property. The analysis of the acceptable behaviour in the confiscation process provides the basis for proposals aiming to improve legislative enactments.
\end{abstract}

Atslēgvārdi: noziedzīgi iegūtais, konfiskācija

Keywords: crime proceeds, confiscation

\section{Ievads}

Ikviens saprātīgi domājošs cilvēks piekritīs tēzei, ka noziedzīgi iegūtais ir jāatṇem. Pirmkārt, taisnīguma vārdā. Nav piel̦aujams, ja kāds iedzīvojas, pārkāpjot sabiedrībā pieṇemtās visiem saistošās uzvedības normas. Turklāt tas notiek negodīgi, uz citu cilvēku rēḳina, l,oti bieži - radot zaudējumu un pārdzīvojumus konkrētam cietušajam. Otrkārt, tas nepieciešams, lai atņemtu mērķi pašai noziedzīgajai darbībai un finansējumu tās turpināšanai. Riskam zaudēt iegūto jābūt patiesi reālam, lai cilvēku piespiestu padomāt, vai vispār ir vērts pārkāpt likumu.

Noziedzīgi iegūto atņemot, turpmākā rīcība ar šo mantu var notikt divos veidos. Ja manta savulaik bija noziedzīgi atsavināta tās ìpašniekam vai likumīgajam valdìtājam, tā ir jāatdod šim cilvēkam, kas kriminālprocesā parasti ir cietušais. Atdošanu īpašniekam vajadzētu saukt par restitūciju. Otrs risinājums - noziedzīgi iegūtā konfiskācija, kas nozīmē tā bezatlīdzības atsavināšanu valsts labā. 
Tā izmantojama procesos, kuros noziedzīgi iegūtā manta nav jāatdod vai to dažādu iemeslu dēḷ nedrīkst atdot īpašniekam.

Šajā rakstā analizēšu tikai konfiskācijas iespējas un pamatu.

\section{Konfiskācijas iespējas}

Latvijas likumi dod samērā plašu iespēju konfiscēt noziedzīgi iegūto gan no materiālo, gan procesuālo tiesību aspekta.

Ir tradicionālā jeb pierādītās noziedzìgi iegūtās mantas konfiskācija, kad kriminālprocesā tiek pierādīta konkrētās mantas noziedzīgā izcelsme. Krimināllikuma 70.11 panta pirmajā daḷā tas noteikts nepārprotami: "manta, kas personas ipašumā vai valdījumā tieši vai netieši nonākusi noziedzīga nodarījuma izdarīšanas rezultātā".

Otra iespēja Latvijas likumos parādījās šā gadsimta sākumā. Sākotnēji Kriminālprocesa likums (turpmāk arī KPL) no 2005. gada paredzēja, ka ar konkrētiem noziedzīgiem nodarïjumiem saistītu personu manta var tikt uzskatīta par noziedzīgi iegūtu. Norma tālāk tika attīstīta 2017. gadā, to pārceḷot uz Krimināllikumu. Likuma $70 .{ }^{11}$ panta otrā daḷa l̦auj par noziedzīgu atzìt arī tādu mantu, kas pieder personai, kurai ir zināma saistība ar konkrētiem noziegumiem (izdarījusi noziegumu, kas pēc sava rakstura ir vērsts uz materiāla vai citāda labuma gūšanu; ir organizētas grupas dalïbnieks vai atbalsta to; ir saistīta ar terorismu) un kuras mantas vērtība nav samērīga ar personas likumīgajiem ienākumiem, ja persona nepierāda, ka manta ir iegūta likumīgā ceḷā. Savukārt panta trešā daḷa l̦auj par noziedzìgi iegūtu atzìt arī tādu mantu, kas atrodas citas tādas personas rīcībā, kura uztur pastāvīgas ǵimenes, saimnieciskas vai citādas mantiskas attiecỉbas ar šā panta otrajā daḷā minēto personu, ja šìs personas rīcībā esošās mantas vērtība nav samērīga ar tās likumīgajiem ienākumiem un ja persona nepierāda, ka manta ir iegūta likumīgā cel̦ā. Teorijā šo konfiskāciju dēvē par prezumētu noziedzīgi iegūtu mantu, jo mantas noziedzīgā iegūšana netiek tieši pierādìta.

Jāatzīst, ka arī Eiropas Padomes dalībvalstīm ar Padomes Pamatlēmumu 2005/212/TI (2005. gada 24. februāris) par noziedzīgi iegūtu līdzekḷu, nozieguma rīku un ìpašuma konfiskāciju ${ }^{1}$ tika noteikta vienota noziedzīgi iegūtas mantas konfiskācijas izpratne. Pamatlēmuma 3. pants paredz paplašinātās konfiskācijas pilnvaras, kas pēc būtỉbas attiecas uz prezumētu noziedzīgi iegūtu mantu, tostarp arī uz tuviniekam piederošu mantu.

Arī Kriminālprocesa likums paredz vairākas iespējas, kad un kādā kārtībā noziedzīgi iegūto var konfiscēt. Šeit ir visiem vienkārši saprotamā jeb tradicionālā noziedzīgi iegūtā konfiskācija kriminālprocesa noslēgumā, kad ir pierādīta nodarījumā vainojamās personas vaina. To paredz likuma 356. panta pirmā daļa: "Mantu par noziedzīgi iegūtu var atzìt ar spēkā stājušos tiesas nolēmumu vai prokurora lēmumu par kriminālprocesa pabeigšanu." Šis nolēmums var ietvert kā pierādìtas, tā arī prezumētas noziedzīgi iegūtas mantas konfiskāciju. Vienīgi prokurora lēmums nevar attiekties uz mantu, uz kuru tiesības reǵistrējamas publiskajā reǵistrā.

1 Padomes Pamatlēmums 2005/212/TI (24.02.2005.) par noziedzīgi iegūtu līdzekḷu, nozieguma rìku un ìpašuma konfiskāciju. Pieejams: https://eur-lex.europa.eu/legal-content/LV/TXT/?uri=celex\% 3A32005F0212 [aplūkots 01.03.2020.]. 
Likums Latvijā paredz iespēju noziedzīgi iegūtu mantu konfiscēt jau pirmstiesas procesa laikā. Saskañā ar Kriminālprocesa likuma 626. panta pirmo daḷu procesa virzìtājs var izdalìt no krimināllietas materiālus par noziedzīgi iegūtu mantu un uzsākt procesu, ja pierādījumu kopums dod pamatu uzskatìt, ka manta ir noziedzīgi iegūta, un objektīvu iemeslu dēl krimināllietas nodošana tiesai tuvākajā laikā nav iespējama vai tas var radìt būtiskus neattaisnotus izdevumus. Šà procesa rezultātā tiesa vērtē, vai mantas noziedzīgā izcelsme ir pierādìta un kāda būtu turpmākā rīcība ar to. Tas nozīmē, ka manta var tikt konfiscēta sevišksāa procesa kārtībā jeb, kā praksē mēdz teikt, 59. nodalalas kārtībā. Jāpiebilst, ka šo nodaļu var izmantot arī mantas atzišanai par noziedzīgu, ja izmeklētājs vai prokurors (attiecībā uz publiskā reǵistrā reg̣istrētu mantu) izbeidz kriminālprocesu ar nereabilitējošu lēmumu.

Minētais procesa veids ir ḷoti progresīvs, taču tas veidots konkrētām procesuālām situācijām, un tas nozīmē, ka šo procesu var īstenot, ievērojot konkrētus likumā ietvertus priekšnosacijumus. To ignorēšana un sevišķā procesa izmantošana jebkuras mantas konfiscēšanai var novest pie Satversmē nostiprināto cilvēktiesību pārkāpšanas. ${ }^{2}$

Ja par noziedzīgu atzīst un konfiscē pierādītu noziedzīgi iegūtu mantu, tas ne teorijā, ne praksē nerada diskusijas. Tāpat saprotams ir arī konfiscēšanas lēmums, kas ietverts galīgajā nolēmumā, kurā tiek pierādìta kādas personas vainojama rīcíba un attiecīgi arī mantas noziedzīgā izcelsme. Tātad teorētiskās un praktiskās problēmas rada mantas atzīšana par noziedzīgu un konfiscēšana pirmstiesas procesa laikā sevišķā procesa kārtībā, it ipaši ja to attiecina uz prezumētu noziedzīgi iegūtu mantu.

\section{Konfiskācijas pamats}

Analīze gan nebūs par materiālajās tiesībās noteikto īpašās konfiskācijas pamatu, jo nav jau strīdu, ka noziedzịgi iegūtais būtu konfiscējams. Reālajā dzīvē aktuālākais jautājums ir par to, vai ir pamatota tieši konkrētās mantas konfiscēšana tieši konkrētajam cilvēkam. Citiem vārdiem, kā tiek pamatota jeb pierādīta konkrētās mantas noziedzīgā izcelsme, lai attiecībā uz to varētu piemērot konfiskāciju. Galveno uzmanību veltīsim sevišķajam procesam.

Kā jau tika norādīts, Kriminālprocesa likuma 626. pants l̦auj uzsākt procesu par noziedzīgi iegūtu mantu, ja ir divi priekšnosacījumi. Pirmkārt, pierādījumu kopums dod pamatu uzskatīt, ka manta ir noziedzīgi iegūta vai saistīta ar noziedzīgu nodarijjumu. Otrkārt, objektīvu iemeslu dēl krimināllietas nodošana tiesai tuvākajā laikā nav iespējama vai tas var radīt būtiskus neattaisnotus izdevumus.

Otrais priekšnosacijums ir vieglāk analizējams, jo realitātē ir viegli saprotamas situācijas, kad mantas glabāšana ir dārgs pasākums (rodas nevajadzīgi un neattaisnojami izdevumi). Par profesionālu dīvainību varētu saukt tādu lēmumu, kurā šo kritēriju piemin lietās par iespējami noziedzịgi iegūtas mantas

2 Sikkāk sk.: Kūtris G. Tiesības uz ìpašumu un īpašuma konfiskācija. Grām.: Satversmē nostiprināto vērtību aizsardzība: dažādu tiesību nozaru perspektīva. Latvijas Universitātes 77. starptautiskās zinātniskās konferences rakstu krājums. Rīga: LU Akadēmiskais apgāds, 2019, 81.-90. lpp.; Kūtris G. Mantas konfiskācija un nevainīguma prezumpcija. Grām.: Tiesỉbu zinātnes uzdevumi, nozīme un nākotne tiesỉbu sistēmās I. Latvijas Universitātes Juridiskās fakultātes 7. starptautiskās zinātniskās konferences rakstu krājums. Rīga: LU Akadēmiskais apgāds, 2019, 353.-365. lpp. 
konfiskāciju. Ja par arestētas naudas nodošanu glabāšanā depozìtā kādam tiešām rodas grūtības vai papildu izdevumi, tad Finanšu ministrijai būtu jāparūpējas par normatīvo aktu sakārtošanu attiecībā uz šādu līdzekḷu uzglabāšanu. Bet kopumā attiecībā uz šì kritērija pieminēšanu lēmumā par sevišḳā procesa uzsākšanu būtu vēlams, ja tiesa no procesa virzītāja pieprasîtu iespējamo izdevumu izskaidrojumu.

Tikpat log̣iski varētu izprast arī norādi uz neiespējamību krimināllietu nodot tiesai saprātīgā laika posmā. It īpaši kriminālprocesos, kuros veicama starptautiskā sadarbība. Tomēr patiesībā šis kritērijs ir galvenais "dzinējspēks" sevišķo procesu uzsākšanai. Pirmstiesas kriminālprocesi notiek nepamatoti ilgi, ${ }^{3}$ un lìdz ar to procesos izṇemtās un arestētās mantas uzglabāšanas termiṇi (KPL 389. pants) reiz beidzas. Lai nebūtu jāatdod iespējami noziedzīgi iegūta manta aizdomās turētajam vai apsūdzētajam, procesa virzìtājs cenšas pierādīt mantas saistību ar noziedzīgo nodarījumu.

Par pierādīšanas pienākumu runāts pirmajā priekšnosacījumā. Likumā visai nepārprotami norādīts: "pierādījumu kopums dod pamatu uzskatīt, ka manta [...". Tātad tiek prasīts pierādijumu kopums, ka manta ir "netīra". Cita starpā teorijā un daudzas ārvalstīs šādu seviškço procesu tieši tāpēc arī sauc "process par lietu" jeb "process in rem". 4

Procesā par noziedzīgi iegūtu mantu pēc būtības pat nav svarīgi, kas ir izdarījis noziegumu. Šeit akcents tiek likts uz konkrētas mantas saistību ar konkrētu noziegumu. Tas ir jāpierāda valstij, ja grib šo mantu konfiscēt. Lai atvieglotu pierādīšanas pienākumu, likumdevējs pat ir pazeminājis kriminālprocesam tradicionālo pierādīšanas slieksni no "ārpus saprātīgām šaubām” uz "visticamāk, ka”. Kriminālprocesa likuma 124. panta sestajā daḷa atrunāts, ka "procesā par noziedzīgi iegūtu mantu pierādīšanas priekšmetā ietilpstošie apstākḷi attiecībā uz mantas noziedzīgo izcelsmi uzskatāmi par pierādītiem, ja pierādīšanas gaitā ir pamats atzìt, ka mantai, visticamāk, ir noziedzīga, nevis likumīga izcelsme".

Saistībā ar šo pierādīšanas standarta mainu, kas savulaik netika zinātniski izvērtēta, veidojas tiesiskuma problēmas. Piemēram, ja personas vaina noziedzīga nodarījuma izdarīšanā ir jāpierāda ārpus saprātīgām šaubām, tad ir pietiekami pierādìt "visticamāk, ka" finanšu līdzekḷi ir noziedzīgas izcelsmes, lai varētu apgalvot, ka personas darbības, kas biznesa pasaulē ir pilnīgi normālas finanšu operācijas, ir kvalificējamas kā noziedzīgi iegūtu līdzekḷu legalizācija. Tādējādi vaina noziegumā būvēta uz pierādījumiem, ka nozieguma priekšmets, visticamāk, ir noziedzīgs. Ja priekšmets nebūtu noziedzīgs, nebūtu paša nozieguma. Iznāk, ka visa apsūdzība un arī notiesājošs spriedums var balstīties uz secinājumu, ka, visticamāk, ir noticis noziegums. Šādu pierādījumu konstrukciju varētu piel̦aut jautājumā par mantas atzīšanu par noziedzīgu un attiecīgi - tās konfiskāciju, bet to nedrīkst izmantot jautājumā par personas vainu.

Otrs piemērs no cita aspekta. Kriminālprocesā uzsākts process par kādas mantas atzīšanu par noziedzīgi iegūtu. Mantas īpašnieks jūtas aizskarts un apgalvo, ka mantu viņš ir ieguvis legāli. Procesa gaitā viṇam ir tiesības savu apgalvojumu pierādìt. Neapšaubāmi personai savu civilo tiesību pierādīšanai ir

Sk.: Vai pirmstiesas izmeklēšana Valsts policijā ir efektīva. Valsts kontroles revīzijas ziņojums. Pieejams: http://www.lrvk.gov.lv/uploads//reviziju-zinojumi/2016/2.4.1-6_2016/rz_vp_20.09.2017_bez-ip.pdf [aplūkots 01.03.2020.].

4 ECT 26.09.2018. spriedums lietā Telbis and Viziteu v. Romania (pieteikums Nr. 47911/15); ECT 12.05.2015. spriedums lietā Gogitidze and others v. Georgia (pieteikums Nr. 36862/05). 
civiltiesiskais pierādī̌̌anas standarts “visticamāk, ka” (manta viṇam pieder likumīgi). Tomēr arī procesa virzìtājam ir tas pats standarts "visticamāk, ka" (mantai ir noziedzīga izcelsme). Tikai spēku samērs abām pusēm šajā "sacīkstē" ir dažāds. Valsts pārstāvis sava apgalvojuma pierādī̌̌anai izmanto valsts pieejamos resursus (kā kriminālprocesā), bet indivīds - savus (kā civilprocesā). Turklāt Latvijā ir konkrēti tiesas lēmumi, kuros redzams, ka tiesa no personas nepieņem (vai atzīst par apšaubāmiem) civiltiesiski iegūtus pierādījumus. Risinājums būtu šo jautājumu par mantas izcelsmi un piederību izskatīt civilprocesuālā kārtībā. Ne velti dažas valstis tā ir rīkojušās un arī starptautiskie dokumenti tā rekomendē.

\section{Prezumpcija kā konfiskācijas pamats}

Krimināllikuma norma, kas paredz iespēju mantu prezumēt kā noziedzīgu, to attiecina uz mantu, kas pieder personai, par kuras noziedzīgo darbỉbu nav šaubu. Likums nepārprotami nosaka - "persona, kura izdarījusi noziegumu, kas pēc sava rakstura ir vērsts uz materiāla vai citāda labuma gūšanu”. Tātad primāri ir jābūt pierādītam, ka 1) konkrētā persona to ir izdarījusi, turklāt 2) tas nav kriminālpārkāpums un 3) ir vērsts uz labuma gūšanu. Atcerēsimies, ka Kriminālprocesa likumā pierādīšanas standarts ir pazemināts attiecībā uz mantu, nevis personas noziedzīgo darbỉbu.

Arī otram likuma normā ietvertajam nosacìjumam - mantas vērtība nav samērīga ar personas likumīgajiem ienākumiem - jābūt pierādītam. Vismaz fiksētam, kādi ir personas oficiāli zināmie ienākumi, lai varētu salīdzināt divus apmērus.

Tikai pēc primāri izpildītā apsūdzības puses pienākuma seko personas tiesības pierādīt pretējo. Kriminālprocesa likumā ir iestrādāts princips, ka tam, kurš kaut ko apgalvo, tas ir arī jāpierāda. Ja persona izvēlas cīnīties par savām tiesībām uz mantu un apgalvo, ka tā ir legāli iegūta, tad tai arī rodas pienākums savu apgalvojumu pamatot. Protams, svarīgi atcerēties, ka personai, kurai ir tiesības uz aizstāvību, ir neapšaubāmas tiesības klusēt (sevi neapsūdzēt). Ja apsūdzības puse savu pierādīšanas pienākumu ir izpildījusi, bet aizstāvības puse klusē, lai gan varētu bez ìpašas piepūles sniegt izskaidrojumu, nenoliedzami gala nolēmums būs par labu apsūdzības apgalvojumam. Šādi secinājumi ir izdarīti arī vairākos Eiropas Cilvēktiesību tiesas spriedumos, proti, dažkārt personai ir pienākums neklusēt. ${ }^{5}$

Ievērojot minētās likuma normas un ar tām saistītos apsvērumus, mantas prezumēšana par noziedzīgi iegūtu varētu notikt tikai ar galīgo nolēmumu kriminālprocesā. Tas it īpaši saistīts ar faktu, ka ir jābūt pierādìtai personas saistībai ar noziegumu.

Protams, Kriminālprocesa likuma 59. nodaḷu ir iespējams izmantot arī citā situācijā, proti, kad process tiek izbeigts uz nereabilitējoša lēmuma pamata (respektīvi, tiek atzīta personas vaina), persona to neapstrīd, bet procesā ir fiksēta manta, kuras vērtība būtiski pārsniedz personas legālos ienākumus. Taču šì iespēja ir vairāk teorētiska, jo maz ticams, ka tiks izbeigti kriminālprocesi ar ievērojamām noziedzīgi iegūtas mantas vērtībām.

5 ECT 07.10.1988. spriedums lietā Salabiaku v. France (pieteikums Nr. 10519/83). 
Šeit nepieciešams vēlreiz uzsvērt, ka sevišḳā procesa kārtỉbā (KPL 59. nodaḷa) nedrīkst prezumēt, ka personai piederošā manta ir noziedzīgi iegūta. Pirmkārt, to nepiel̦auj jau minētais Kriminālprocesa likuma 626. pants, kurš prasa pierādījumu kopumu par mantas noziedzīgo izcelsmi. Otrkārt, šajā procesā netiek vērtēta personas, kurai pieder manta, vaina kāda nozieguma izdarǐ̌anā. Pat tad, ja ir kāds agrāks tiesas spriedums par personas izdarìto noziegumu, piemēram, par krāpšanu, sevišķā procesa kārtībā nevar tikt vērtēti pierādijumi, vai krāpšanas darbībās iegūto labumu vērtība nav bijusi lielāka. Tas jau attiektos uz personas vainas izvērtēšanu (ko un cik daudz izdarijja). Vēl vairāk, pati sevišķā procesa uzsākšana šādos gadījumos izskatītos tiesiski apšaubāma.

Analizējot minētos jautājumus, teorijā un praksē nereti tiek piesaukts jēdziens "predikatīvais noziegums". Vai tam ir jābūt fiksētam, lai mantu varētu atzìt par noziedzīgi? Viennozīmīgi - jā. Nevar taču atzìt mantu par noziedzīgu, ja nav zināms, kāds noziegums vispār ir izdarìts (kādā noziegumā iesaistìta persona, kuras mantu vēlamies konfiscēt). Dažkārt diskusijās tiek pieminēta Eiropas Cilvēktiesību tiesā izskatìtā lieta Čušens (Zschüschen) pret Belğiju, ${ }^{6}$ no kuras izriet, ka nacionālā tiesa nav pārkāpusi Eiropas Cilvēktiesību konvenciju, notiesājot personu par noziedzīgi iegūtu līdzekḷu legalizāciju un konfiscējot mantu, lai gan persona nav tiesāta par predikatīvo noziegumu. Taču jāievēro, ka, pirmkārt, tas bija galīgais tiesas nolēmums par personas vainu noziegumā, otrkārt, tiesa norādīja uz vairākiem faktiem, kas izskaidroja konkrētās naudas izcelsmi no darbībām ar narkotiskām vielām (personas agrākā saistība ar tām ir bijusi zināma), treškārt, personai nebija legālu ienākumu un tā nespēja izskaidrot lìdzekḷu izcelsmi, un, ceturtkārt, netika piemērota paplašinātā konfiskācija.

Vairāki praksē redzētie tiesas lēmumi un rīcība dod pamatu pievērst uzmanību aplūkotajam jautājumam, kas nākotnē var radìt būtiskas problēmas valstij. Īpaši aktuāli tas ir saistībā ar uzsākto bezkompromisa cinnu pret noziedzịgi iegūto lìdzekḷu legalizāciju, kur mērḳa sasniegšanai ne pārāk tiek pievērsta vērība līdzekḷu tiesiskumam jeb, precīzāk, to tiesiskai piemērošanai.

Piemēram, tiek atrasti neskaidras izcelsmes naudas lìdzekḷi, un, ja īpašnieks nespēj vai negrib (dažkārt - tiesa pat neatzīst par pamatotu) izskaidrot to izcelsmi, tiek uzsākts kriminālprocess par noziedzīgi iegūtu līdzekḷ legalizēšanu. Apzinoties, ka šo noziegumu "saprātīgā laika posmā" neizdosies pierādīt, jo visbiežāk darbỉbas ir saistītas ar citām valstīm, procesa virzītājs uzsāk procesu par noziedzīgi iegūtu mantu un materiālus nodod tiesai. Tiesas mēdz atzìt, ka naudas līdzekḷi "visticamāk" ir noziedzịgi iegūti, un nolemj tos konfiscēt. Turklāt nav pat svarīgi, ka citā valstī kriminālprocess par iespējamo predikatīvo noziegumu pret naudas īpašnieku ir izbeigts vai nav vēl nodots tiesai (prokuratūras informācija tiek uzskatīta par pierādījumu personas vainai), vai arī persona jau bijusi notiesāta par noziedzīgi iegūtā legalizēšanu (tiek ignorēts ne bis in idem princips!). Konfiskācija notiek.

Šajos procesos neviens nerisina jautājumu, vai kādam cietušajam nebūtu tiesības uz šo mantu. Tāpēc praksē valstij ir nācies samaksāt no līdzekḷiem neparedzētiem gadijiumiem vēlāk noskaidrotajam cietušajam. Šajos procesos netiek domāts, kas atlīdzinās zaudējumus īpašniekam, ja pamata kriminālprocesā netiks pierādīta personas vaina. Pat tad, ja būs attaisnojošs jeb reabilitējošs nolēmums, jo likums jau neparedz, ka procesa virzìtājam ir pienākums vai tiesības

6 ECT 02.05.2017. spriedums lietā Zschüschen v. Belgium (pieteikums Nr. 23572/07). 
pārvērtēt pirmstiesas procesa laikā sevišķā procesa kārtībā pieņemtā lēmuma, pēc būtības starplēmuma, pamatotību. Var jau, protams, norādīt, ka ir Kriminālprocesā un administratîvo pārkāpumu lietvedībā nodarîtā kaitējuma atlīdzināšanas likums, taču tas neparedz atlīdzību pat pilnā apmērā, nerunājot nemaz par neiegūtā labuma atlīdzināšanu.

Noslēgumā varētu tikai uzsvērt, ka no daudzām norādītajām problēmām izvairīsimies, ja praksē tiesību normas tiks piemērotas prasmīgi, apzinoties atbildỉbu par tiesiskuma nodrošināšanu. Savukārt likumdevējam tiesību sistēmas sakārtošanā būtu jāieklausās tiesību zinātnes atziņās, kas palīdz saskatìt atškírību starp vēlamo un pię̧aujamo.

\section{Kopsavilkums}

1. Diskutējot par noziedzīgi iegūtas mantas konfiskāciju, nepieciešams norobežot konfiskāciju, kas ir mantas bezatlīdzības atsavināšana valsts labā, no restitūcijas, kas ir mantas atdošana tās sākotnējam (patiesajam) īpašniekam.

2. Nav diskusijas par pierādìtas noziedzīgi iegūtas mantas konfiscēšanu, it īpaši ja tas notiek ar galīgo nolēmumu kriminālprocesā.

3. Seviškā procesa uzsākšanas priekšnosacỉjumu ignorēšana un šā procesa izmantošana jebkuras mantas konfiscēšanai var novest pie Satversmē nostiprināto cilvēktiesību pārkāpšanas.

4. Pierādīšanas standarta maina no "ārpus saprātīgām šaubām" uz "visticamāk, ka" radījusi vairākas tiesiskuma problēmas. Vaina noziegumā var tikt balstìta uz pierādījumiem, ka nozieguma priekšmets, visticamāk, ir noziedzīgs. Ja priekšmets nebūtu noziedzīgs, nebūtu paša nozieguma. Lìdz ar to visa apsūdzība un pat notiesājošs spriedums var balstīties uz secinājumu, ka, visticamāk, ir noticis noziegums. Pazeminātais pierādišanas standarts kaut vai uz vienu no apsūdzības elementiem nav piel̦aujams jautājumā par personas vainu.

5. Jautājumi par kādas mantas patieso dabu - vai tā ir noziedzīgas izcelsmes vai ar noziegumu saistìta, vai arī tiesiski pieder kādai personai - būtu izskatāmi civilprocesuālā kārtībā, ievērojot Civilprocesa likumā noteiktos pierādišanas standartus un izmantojot tajā piẹ̦autos pierādijumus.

6. Mantas prezumēšana par noziedzīgi iegūtu var notikt tikai ar galīgo nolēmumu kriminālprocesā, jo tas ir saistìts ar mantas piederību konkrētai personai, savukārt personas saistībai ar noziegumu ir jābūt pierādìtai. 